\title{
Promoting Malaysian “Batik" pattern through Automotive Interior Design
}

Muhammad Fitri Samsuddin, Siti Nurul Akma Ahmad, Mohd Hisham Johari, Azni Hanim Hamzah, Raziq Abdul Samat

To Link this Article: http://dx.doi.org/10.6007/IJARBSS/v8-i12/5377

DOI: $10.6007 /$ IJARBSS/v8-i12/5377

Received: 04 Dec 2018, Revised: 30 Dec 2018, Accepted: 11 Jan 2019

Published Online: 13 Jan 2019

In-Text Citation: (Samsuddin, Ahmad, Johari, Hamzah, \& Samat, 2018)

To Cite this Article: Samsuddin, M. F., Ahmad, S. N. A., Johari, M. H., Hamzah, A. H., \& Samat, R. A. (2018). Promoting Malaysian "Batik" pattern through Automotive Interior Design. International Journal of Academic Research in Business and Social Sciences, 8(12), 2036-2043.

\section{Copyright: (C) 2018 The Author(s)}

Published by Human Resource Management Academic Research Society (www.hrmars.com)

This article is published under the Creative Commons Attribution (CC BY 4.0) license. Anyone may reproduce, distribute, translate and create derivative works of this article (for both commercial and non-commercial purposes), subject to full attribution to the original publication and authors. The full terms of this license may be seen at: http://creativecommons.org/licences/by/4.0/legalcode

\section{Vol. 8, No. 12, 2018, Pg. 2036 - 2043}

Full Terms \& Conditions of access and use can be found at http://hrmars.com/index.php/pages/detail/publication-ethics 


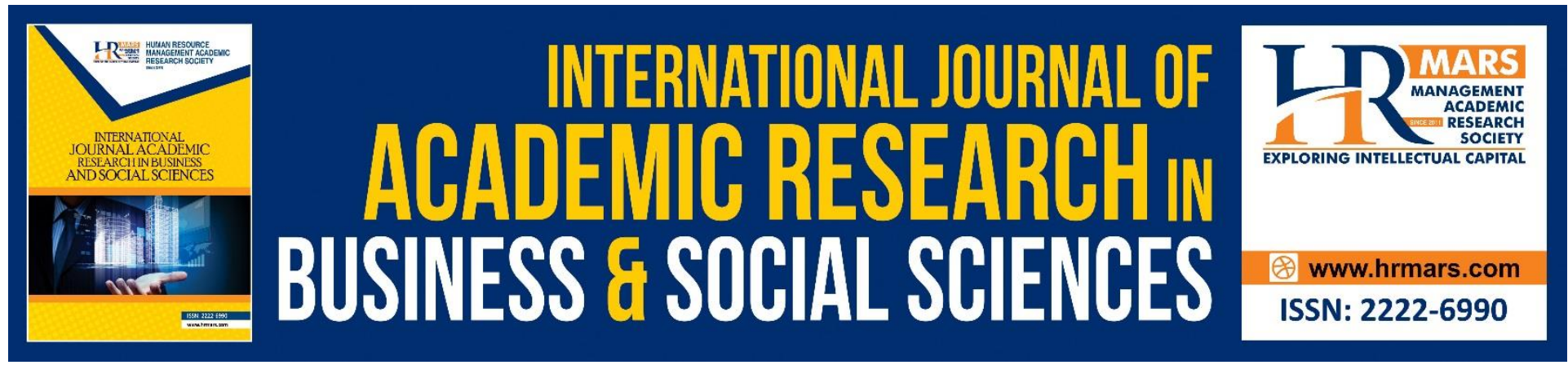

\title{
Promoting Malaysian "Batik" pattern through Automotive Interior Design
}

\author{
Muhammad Fitri Samsuddin, Siti Nurul Akma Ahmad, Mohd \\ Hisham Johari, Azni Hanim Hamzah, Raziq Abdul Samat \\ Universiti Teknologi MARA, Melaka, Malaysia
}

\begin{abstract}
Batik industry in Malaysia has started with small-scale operations that later have progressively developed into a profitable cottage industry as well as national enterprise. The batik pattern is widely applied on clothes especially among Asian and gradually the design has expanded to other accessories like handbag, shoes, wall frame, pillow sheet cover and few others. Batik pattern has high potential to be applied on other platforms not limited to the clothes. Batik pattern and its product, which is known as part of creative industry, are possible to continuously develop. More efforts need to be emphasize in promoting the batik pattern. Therefore, this study is carried out with the aim of expanding the promotion of batik pattern not only by conventional approach of exhibitions and selling products but also through the visibility of exclusive batik interior design specifically in Malaysia public transports. The collaboration between batik producer and automotive industry representative aims to strategize the coverage of batik pattern in Malaysia public transports including rail networks facilities, bus, taxi and trishaw. This study plan to involve two setting which are Klang Valley and Melaka since Klang valley is the leading state with fully equipped by various mode of public transport while Melaka is chosen due to its largest tourism attraction in Malaysia. Furthermore, the idea is potentially contribute to the new opportunities for Malaysia batik producers in expanding their design not merely on the clothes fabric but also towards the interior automotive fabric design. This will turn into additional profit making and increasing economic growth as well as expanding the Malaysian Batik industry.
\end{abstract}

Keywords: Batik Pattern, Automotive Interior Design, Public Transport, Art and Heritage 


\section{INTRODUCTION}

Batik is well recognized as the art heritage with high artistic value (Nurul, Supadi and Lasmedi, 2013). In general, batik refers to decorative fabrics with various colors and patterns. As an origin, the term batik is come from the Javanese word of 'tick' which means to drip or write points and 'Ambatik' which mean to draw, write, paint or drip (Rohaida, and Siti, 2012).

Instead of Malaysia, batik is also well recognized in Indonesia as batik producer in the region however, each country has apllied different batik motive and style. Malaysian batik differs from other styles in the region by its identity including hand drawing techniques and its motive as well as patterns due to its distinct nature and unique appearance that inspired from floral and geometric designs (Rohaida and Siti, 2012).

The batik pattern is widely applied on clothes especially among Asian and gradually the design has expanded to other accessories like handbag, shoes, book mark, wall frame, pillow cover and few others. Batik design has high potential to be applied on other platforms not limited to the clothes. Batik design and its product, which is known as part of creative industry, are possible to continuously develop (Santi, Utomo and Pri, 2015). In Malaysia, batik is part of the preserved culture and it represents Malaysia's cultural identity where its potential should not be neglected (Sharifah, Chuah, Hossein, 2013).

More efforts need to be emphasize in promoting the batik design. However, there is still limited marketing strategy is coneventionally carried out by most of craftsmen. The most common marketing strategy carried out includes a simple exibition held by the local government which targeted among the local people. This limited exhibition is due to lack of capital to finance the larger exibition as well as the lack of promotion and sales skilled professionals (Nurul, Supadi and Lasmedi, 2013). Therefore, this study is carried out with the aim of expanding the promotion of batik design not only by conventional approach of exhibitions and selling products but also through the visibility of exclusive batik interior design specifically in Malaysia public transport.

\section{Malaysian Batik Industry}

Batik industry in Malaysia has started with small-scale operations which later have progressively developed into a profitable cottage industry as well as national enterprise. Malaysian batik is popular both domestically and abroad where batik is third in popularity among corporate buyers, after pewter and woodcraft products (Rohaida, and Siti, 2012). In Malaysia, most of the batik producer or batik factory was found in Kelantan and Terengganu (Sharifah, Chuah, Hossein, 2013). The Malaysian batik has become a sought after product by consumers and tourists (Nurul, Supadi and Lasmedi, 2013).

Since 1979, the Malaysian Handicraft Development Corporation (Malaysian Handicraft) is responsible to promote the marketing and export of handicraft products including batik. This is seen as continuous governmental efforts to promote batik production as an artistic product in Malaysia (Nurul, Supadi and Lasmedi, 2013). According to Rohaida Nordin study, the effort has resulted in displaying and selling Malaysian batik in overseas outlets, such as Harrods of London. The Malaysian 
INTERNATIONAL JOURNAL OF ACADEMIC RESEARCH IN BUSINESS AND SOCIAL SCIENCES

Vol. 8, No. 12, Dec, 2018, E-ISSN: 2222-6990 @ 2018 HRMARS

batik has become a sought after product by consumers and tourists (Nurul, Supadi and Lasmedi, 2013).

As a developing country, Malaysia should optimize its batik natural reserves and cultural varieties by enhancing the tourism industry (Sharifah, Chuah, Hossein, 2013) and strengthening the promotion of batik across industries like automotive through the platform of transport interior design.

\section{Existing Batik Promotion Strategies}

Existing literature reveals that batik promotion activities conducted by craftsmen are still using conventional promotion strategy through exhibitions and personal selling. Another conventional methods used by most of craftsmen to promote batik products is by word of mouth approach (Rahab et al., 2013).

Besides those conventional approaches, few scholars have evolved with additional approaches. Kartajaya et al., 2003 and Rahab et al, (2013) in their studies mentioned that an integration of multiple promotional strategies through marketing mix is necessary to promote batik. While Nurul Anwar, Supadi, Rahab \& Lasmedi Afuan, (2013) study suggest wider promotion design by using website application as an online promotion strategies could be another alternative promotion strategies. This strategy is expected to provide wider coverage at a lower price for promoting batik products. This is also consistent with the idea of Lichtenthala and Shay who also agreed that the growth of digital technology and Internet should be benefits in providing greater opportunities for batik craftsman to market their product (Lichtenthala and Shay. 2009).

Furthermore, another strategy has been carried out in an effors of promoting batik by developing one-stop centre in Johor, a state in Malaysia. The Malaysia Batik Art Integrated Centre with the concept of combining Batik art workshop together with the tourism promotional center is developed as a platform for artisan and it is targeted for the tourist and the local adults as well as children. This one-stop centre will provide a unique and valuable experience as a medium to interact with the art of Malaysia batik. These could also served as a platform to new generation and master designers in sharing their thoughts and ideas as well as to strengthen and interpret the uniqueness of batik design in reflecting Malaysian local identity and culture for public awareness (Sharifah, Chuah, Hossein, 2013).

Thus, greater public awareness on the batik design and its uniqueness should be continuously and innovatively expanded through various medium or platforms. This study will discuss further on the proposed idea of expanding the promotion of Malaysia batik design in a different perspective, which involves an automotive industry.

\section{Novel Batik Promoting Strategy in Automotive Industry}

Part of the largest contributor to the state's economy is through tourism. Thus, Malaysia has to grab the opportunities to revive the batik industry. Efforts should be focus on the growth and progress of the Malaysian Batik industry, encouraging innovation in batik design, to find and create markets for 
the consumption of batik products, and to reinforce batik as inherent part of Malaysia identity and personality are the main goals that need to be realized (Sharifah, Chuah, Hossein, 2013).

Therefore, this study aims to expand the batik promotion strategies in automotive industry by introducing the batik design in automotive interior design. As an introduction of the idea, pulic transport facilities are chosen as a study's focus. The future commercialization will be expanded to the interior design of personal transports. This strategy will indirectly expand the coverage of batik visibility and awareness among Malaysian and specifically the targeted international tourists who heavily use the public transport.

\section{Malaysia Public Transports}

Malaysia public transport system, which governs by the Land Public Transport Commisson is divided into four platforms includes rail network, busses, taxi and freight and tourism. Rail network continues to be the backbone of Malaysia's existing and future public transport system. Rail network consists of Electric Train Service (ETS), light rail transit (LRT), Mass Rapid Transit (MRT) and upcoming project, Kuala Lumpur-Singapore High Speed Rail (HSR).

Daily ridership for urban rail services rose $8.5 \%$ to 631,988 commuters in 2015 from 557,921 in 2011, the annual ridership for rail throughout Malaysia for 2014 stands at 230 million. Daily ridership for urban rail services rose 8.5\% to 631,988 commuters in 2015 from 557,921 in 2011 (Malaysian Land Public Transport Commission, 2017). Another public transport platform is buses. In Peninsular Malaysia, the stage bus annual ridership for 2014 stood at 68 million for areas other than Kuala Lumpur, and 155 million for Kuala Lumpur alone. This represents about $70 \%$ of stage bus ridership in Malaysia. The Land Public Transport Commisson has developed myBAS under the Stage Bus Transformation Programme (SBST), Bus Rapid Transit (BRT) system and Bus Network Revamp (BNR). Other available public transports include taxi and trishaw.

Based on the increasing heavy usage of public transport in Malaysia, the researcher views this trend as a great opportunities as a platform to expand the promotion of batik design through public transport interior design.

\section{IMPLEMENTATION STRATEGY}

In realizing this idea, the researchers are in the efforts of collaborating with few stakeholders including the batik producer, Malaysia representative automotive industry (PROTON), Malaysian Handicraft and Land Public Transport Commission. The collaboration aims to strategize the coverage of batik pattern in Malaysia public transports including rail networks facilities, bus, taxi and trishaw (which locally popular in Melaka and Penang).

This study plan to involve two setting which are Klang Valley and Melaka since Klang valley is the leading state with fully equipped by various mode of public transport while Melaka is chosen due to its largest tourism attraction in Malaysia. One of each public transport mode will be chosen as a study 
INTERNATIONAL JOURNAL OF ACADEMIC RESEARCH IN BUSINESS AND SOCIAL SCIENCES Vol. 8, No. 12, Dec, 2018, E-ISSN: 2222-6990 @ 2018 HRMARS

case in designing its interior by exclusive batik design. The details strategy is presented in the below table.

\begin{tabular}{|l|l|}
\hline \multicolumn{1}{|c|}{$\begin{array}{c}\text { Mode of } \\
\text { Public } \\
\text { Transport }\end{array}$} & \multicolumn{1}{|c|}{$\begin{array}{c}\text { Propose Section for } \\
\text { Batik Pattern }\end{array}$} \\
\hline Buses & $\begin{array}{l}\text { Seat Cover and Roof } \\
\text { Panel }\end{array}$ \\
\hline $\begin{array}{l}\text { ETS, LRT, } \\
\text { MRT, HSR }\end{array}$ & Seat Cover \\
\hline Trishaw & Seat Cover \\
\hline Taxi & $\begin{array}{l}\text { Seat Cover and Side Door } \\
\text { Panel }\end{array}$ \\
\hline
\end{tabular}

Table 1: The Proposed Design Section

The Proposed Design

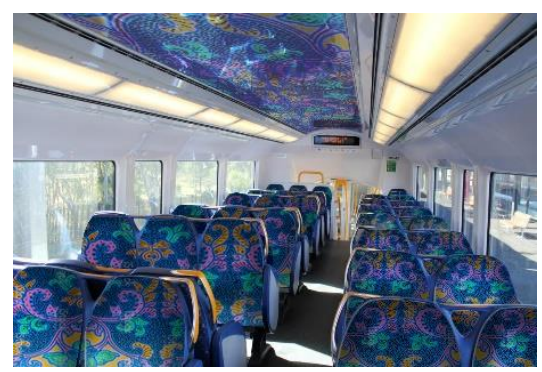

Image 1 - Batik Pattern in Bus Interior

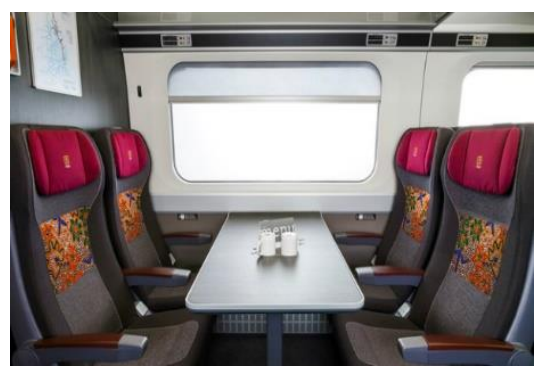

Image 2 - Batik Pattern in LRT Seater 




Image 3 - Batik Pattern on Trishaw

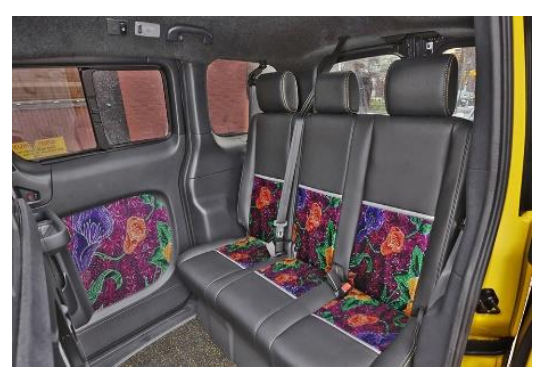

Image 4 - Batik Pattern in Taxi Interior

\section{CONTRIBUTION OF THE STUDY}

\section{Contribution to Batik Producer}

This study will provide new opportunities to the batik producer in expanding their business. Previoulsy batik pattern is only printed in clothes, as official attires for government servants and other formal sector employees. However, with the new proposed idea, batik producer shall expand their business towards public transport companies by providing a design to be applied in public transports vehicles. This would create another profit making and economic growth in batik industry.

\section{Contribution to Public Transport Industry}

The new proposed idea will enhance the image of public transport in Malaysia with a new look of attractive batik motive interior design. Besides, the role of public transport and its driver is also expanded, not only as a tourist guide who provide transportation to the tourists but also as a tourism representative to introduce batik motive as Malaysian identity to the tourists.

\section{Contribution to Malaysian Handicraft}

The collaboration with Malaysian Handicraft will indirectly facilitate the effort of batik promotional strategies conducted by this organization. This idea will increase the diversification of batik product from only clothes and accessories to other medium which is more visible at anywhere especially in public area. 
INTERNATIONAL JOURNAL OF ACADEMIC RESEARCH IN BUSINESS AND SOCIAL SCIENCES

Vol. 8, No. 12, Dec, 2018, E-ISSN: $2222-6990$ C 2018 HRMARS

\section{Contribution to Malaysia Tourism Industry}

With this effort, the diversification of batik pattern will indirectly help Malaysia Tourism Industry to promote Malaysian identity as well as creating a special nich and distinction of public transport with batik interior design which possibly available only in Malaysia.

\section{CONCLUSION}

In realizing this efforts, the collaboration, support and participation by many parties is deemed vital. The main focus of this promotional strategy is to increase public awareness and expose the batik design to be more visible at any time and any location specifically to the targeted tourists. Furthermore, the idea is potentially contributed to the new opportunities for Malaysia batik producers in expanding their design not merely on the clothes fabric but also towards the interior automotive fabric design. This will turn into additional profit making and increasing economic growth as well as expanding the Malaysian Batik industry.

\section{REFERENCES}

Kartajaya, H., Hermawan, M., Yuswohady, Taufik, Sonni, Anwar, H., Joewono, H.H., dan Mussrj, J. (2003). MarkPlus on Strategy. Penerbit PT. Gramedia Pustaka Utama. Jakarta.

Lichtenthala, J. D. and Shay, E. (2009). Internet integration in business marketing tactics.Industrial Marketing Management,Vol. 32, pp. 3- 13

Malaysian Land Public Transport Commission. Retrieved December 2017 from https://www.spad.gov.my/land-public-transport/rail/railing-future Nurul, A., Supadi, R. \& Lasmedi, A. (2013). Strategy to Increase Competitiveness of Batik Banyumasan. International Journal of Business and Social Science, 4(4), 305-311.

Rahab, N. A., Supadi, L. A. (2013). Promotion Mix Strategy For Improving Competitiveness of Batik Banyumasan, Proceeding on "3rd International Conference on Multidisciplinary Research" (ICMR 2013), February, 7-9, 2013 in La Consolacion College, Bacolod City, Philiphina.

Rohaida, N., \& Siti, S. A. B. (2012). Malaysian Batik Industry: Protecting Local Batik Design By Copyright And Industrial Design Laws. International Journal of Business and Society, 13(2), 117 132.

Santi N., Utomo, S. P. \& Pri, H. (2015). Value Orchestration Platform: Promoting Tourism in Batik Industrial Cluster Solo. Procedia - Social and Behavioral Sciences 169. 207 - 216

Sharifah, S. S. M., Chuah, P. J, Hossein, S. (2013). Development of Historical Culture Tourism Industry through Batik Art to Attract the Local and Tourist. Malaysia Batik Art Integrated Centre 2013/2014. 